\title{
NO-VALUE GENERATION? SUCCESS IS AN 'EXACT SCIENCE' THAT EVERYONE CAN LEARN!
}

\author{
RODOLFO G. S. P. G. PRATES, ISABELA L. SANTOS, JARDEL N. MARTINS, \\ FABIANA S. A. MARTINS, AND FELIPE F. COUTO \\ Universidade Estadual de Montes Claros (Unimontes)
}

To cite this paper: Prates, R. G. S. P. G., Santos, I. L., Martins, J. N., Martins, F. S. A., \& Couto, F. F. (2018). No-value generation? Success is an 'exact science' that everyone can learn! Revista de Administração Mackenzie, 19(2). doi:10.1590/1678-6971/eRAMG180088

Submission: Aug. 07, 2017. Acceptance: Nov. 17, 2017.

\section{(cc) BY} This is an open-access article distributed under the terms of the Creative Commons Attribution License.

\footnotetext{
This paper may be copied, distributed, displayed, transmitted or adapted if provided, in a clear and explicit way, the name of the journal, the edition, the year and the pages on which the paper was originally published, but not suggesting that RAM endorses paper reuse. This licensing term should be made explicit in cases of reuse or distribution to third parties. It is not allowed the use for commercial purposes.

Este artigo pode ser copiado, distribuído, exibido, transmitido ou adaptado desde que citados, de forma clara e explícita, o nome da revista, a edição, o ano e as páginas nas quais o artigo foi publicado originalmente, mas sem sugerir que a RAM endosse a reutilização do artigo. Esse termo de licenciamento deve ser explicitado para os casos de reutilização ou distribuição para terceiros. Não é permitido o uso para fins comerciais.
} 


\section{ABSTRACT}

Purpose: The general objective is to critically analyze the ideologies and constructions of management ideology in the Internet blog called Geração de Valor (Generation of Value), behind the discourse of success.

Originality/value: The pop-management phenomenon has been widespread in the Brazilian context. It leads individuals to look for formulas of excel and achieve success as entrepreneurs. One of the disseminators of this ideology has been Geração de Valor. This article innovates when dealing with thematic without prima donna behaviors or fanciful romanticism. Design/methodology/approach: This article aims to analyze texts available on Geração de Valor through critical discourse analysis (CDA). Findings: We conclude that the voice of the businessman and blogger Flávio Augusto da Silva is nothing more than one of several voices, including in administration, that seek to defend the cult of personal victory and disdain for the collectivist practices of social organization. This kind of analysis is still scarce in this field of study, as they require enriched readings of the text in terms of context and intertextuality. Critical analyses contradict hegemonic visions and sharpen the reader's critical sense. Also, they are useful in highlighting the cult following that Administration has been receiving by the media.

\section{KEYWORDS}

Management. Ideology. Power. Critical Discourse Analysis. Critical Theory. 


\section{TALES OF MANAGEMENT AND SUCCESS: IS SUCCESS REALLY ACCESSIBLE TO EVERYONE?}

In times of recession, we need stories that make us believe in our potential to overcome adversity and achieve success. This is precisely the context in which Brazil has been inserted since 2014. At the very moment when this paper is being written, Brazil's unemployment rate is breaking its historical high and reaching a maximum of $13.3 \%$ of the country's workforce (Brazil, 2017). The "career gurus" take part in this theme and disseminate ways to escape from this scenario with stories that resemble fairy tales, in which the good always defeats evil. The villains, in this case, are the adversities that individuals find along the way. In such stories, the respective authors incite subjects to achieve success, regardless of the social and economic context in which they are inserted. Therefore, from this perspective, all of us could achieve success, which would depend only on our own efforts (Wood Jr. \& Paula, 2002).

The pop-management phenomenon has never been as popular in Brazilian contemporaneity as it is now. It leads individuals to look for formulas of excel and achieve success as entrepreneurs, or simply to look for a means of survival at politically and economically turbulent times. This movement (empowered by the dream of success) gains strength by inciting feelings of fear, instability, and insecurity on the population. This phenomenon can be understood from practices that were previously conceived only in organizations, which started to pervade human social life with goals, objectives and control mechanisms, but which now concerns their private and intimate relationships (Oltramari, Friderichs, \& Grzybovsk, 2014).

One of the disseminators of this phenomenon in Brazil has been the blog Geração de Valor. Its founder, Flávio Augusto da Silva, resorts to a Facebook page, his blog and his books to disseminate different formulas to lead a successful life. He is a recent administration guru and has attracted over 3 million followers known as "GVs." On his online posts, we can find messages praising typical propositions from management ideology. Hence, managerialism, the cult of performance and entrepreneurship are recurrent points in his writings. The blog is currently one of the most significant advocates in the field, along with Brazilian business magazines and other publications that have been previously researched (Wood Jr. \& Paula, 2002; Ituassu \& Tonelli, 2014; Oltramari et al., 2014). 
This paper is based on the critical humanist perspective of administration and has an applied approach. It aims to analyze texts found on Geração de Valor by using critical discourse analysis as a research tool. The overall goal is to identify management ideologies and constructions embedded in the discourse of success. By using CDA (Fairclough, 2003), we aim to reverse the opacity of the linguistic material presented by Geração de Valor and shed light on the power practices exercised and hidden in discourse, as well as the social practices applied to convince individuals and the respective implications of their narratives.

To achieve this purpose, we turn to the following research question: what are the implicit discursive structures and elements concerning the power practices and the reproduction of management in discourses presented by Geração de Valor? To answer this question, this paper was subdivided into six sections. This introduction is followed by the theoretical framework consisting of management ideology, pop-management phenomenon, and business literature, respectively; the third section explores the analysis method proposed by CDA and, soon after, describes the object of analysis; the analysis and the final considerations follow, along with a summary of this paper's achievements; the sixth and final section presents the references.

\section{MANAGEMENT AND ADMINISTRATION: THE IDEOLOGY BEHIND THE SCIENCE}

Management ideology is a contemporary phenomenon based on the idea of true and scientific management knowledge. From "true knowledge," one assumes the existence of a "right way" or a "proper method" to perform management. Therefore, these practices support the proliferation of techniques and models for organizational control, aiming to produce profits. In this sense, management ideology is considered an order of light in the chaos that permeates organizations (Ituassu \& Tonelli, 2014). According to Santos, Fonseca, and Sauerbronn (2014), the phenomenon emerged through the work of Frederik Taylor, grounded on the belief in the applicability of scientific techniques in any context to leverage production through the search for control, effectiveness, efficiency and maximization of results.

It is indeed an ideological configuration because it is genuinely part of the ideological assumption that everything around men is controllable through management. This ideology not only concerns the management of the organizations but is transposed to all dimensions of human life 
(Rampazo, 2015). How many of us do not control our own time? How many times have we blamed ourselves for the lack of planning that led to failure? Management ideology takes on the discourse that failure can be prevented and the way to achieve this is through management and its correspondent techniques and models.

As Žižek (1996) says, ideologies are present in the filters that teach us how to perceive reality and can be attributed to anything, from an unrelated contemplative attitude and its dependence on social reality, to the false and naturalized ideas that legitimize a given dominant power. Ideologies mix with our perceptions and teach us how to interpret reality; more than that, they seek to disappear under the veil of naturalization that is evident to those who believe to be ideologically neutral (Žižek, 1996).

We are particularly interested in a thesis derived from this particular ideology: the problem is never management itself, but instead, the lack of management. The lack of management techniques is mainly responsible for one's failure. The secret of success becomes, in this sense, the behavior that must be adopted and the techniques to be applied. Whoever dominant management is capable of dominating the world. Thus, business knowledge has become the knowledge of real success. It is started, then, as a triggerin by the specialized media, in which preset formulas are spread for individuals to behave in social and organizational life - always, of course, with the intention of achieving success in their personal goals (Rampazo, 2015).

It is possible to give some examples of journals and books that have already been studied from a discursive perspective of management ideology in Brazil, such as 1. Revista Exame, analyzed by Ituassu and Tonelli (2014); 2. Revista Você S/A, researched by Oltramari, Friderichs, and Grzybovsk (2014), as well as 3. O Monge e o Executivo, a book analyzed by Carvalho, Carvalho, and Bezerra (2010). In all these cases, authors revealed practices to induce the individual - usually poor and hardworking - to engage in some sort of behavior desired by the dominant business classes.

According to Wood Jr. and Paula (2006), the successful dissemination of management ideology has occurred through four pillars that helped popularize it across the globe. The first pillar is the university, with its manuals to be followed and with "scientific" techniques and procedures. The second one is the figure of management gurus, who talk about their journey to success and "become heroes" for having accomplished their path successfully. The third pillar is the specialized management and business media, which "sell" the success of different people within the market. Finally, the fourth pillar consists of the consultancy and specialized services 
organizations and consultancy organizations, which sell mechanisms and management techniques under the promise of unconditional success. Barros (2014) adds a fifth pillar, consisting of multinational companies as disseminators of such ideology. Management itself has been shown as an ideology of promoting excellence, where organizations and individuals should follow in its footsteps.

The ideologies, according to Wood Jr. and Paula (2006), linked to management are those of a free market society, where every individual has the opportunity to grow, both in organizations and in their personal life - a true ideal of merit. Along these lines, Ituassu and Tonelli (2014) understand that management is the pure creation of an entrepreneurial vision of success linked to the cult of excellence, seeking both individual and collective perfection - just as a venture. Every aspect of life (family, religion, and labor, for example) is rationalized in search of efficiency and mastery, regardless of the setting where the individual is in terms of, income, social or political characteristics - or any other variable that can interfere in the cult for success.

Three important phenomena are inserted in this ideological model. According to Ituassu and Tonelli (2014), the first one is managerialism: a view that everything can and should be controlled, just as everything should be under control. The authors cite the will to control, to have excellence in processes and to hold profits as positive factors, especially in complex cases. However, it is important to stress that managerialism aims to coordinate processes, not the subjectivity of individuals. When used in people, human aspects are not considered, which places subjects in a mechanized situation and implies the loss of human values of work - man, thus, is transformed into an organizational resource competing without limits against others, and excluded if they cannot cope well with stress.

The second phenomenon is the culture of entrepreneurship. The traits of the entrepreneur are regarded as heroic by the management literature proactivity, organization, stamina, innovation, and energy are seen as desirable qualities for all people. If one of these qualities is not detained, the subject is doomed to be inferior, living in a position of failure or unproductivity. Every person's life becomes one great enterprise - everyone should organize, plan, set goals and objectives for themselves. According to this view, these aspects can always lead individuals to success, regardless of particularities and singularities such as social background, income or gender. In this sense, a myth is created, where every subject can be a successful entrepreneur, with access to ample opportunity, which is not necessarily true in all the different contexts. 
In management ideology, the individuals who have robust entrepreneurial features do not fear hard work or get tired until they achieve their aspirations, are committed to results, and associate every failure with a lack of managerial ability or capacity for pursuing goals (Rampazo, 2015; Paula, 2016). In this sense, the Homo entreprenaurus becomes a contemporary form of understanding the human ethos, which now must show an opportunistic, dynamic, self-confident personality and with less risk aversion (Uusitalo, 2001). Management, as an activity, loses its dialogical and constructive feature to become a set of results delivered through systematic management processes aimed at guaranteeing performance, continuously associated with profitability (Paula, 2016).

The third and final phenomenon is the cult of performance. According to this view, one must seek to be the best, the pioneer, the innovator, the one who does everything to achieve excellence, becoming a flawless individual or a role model, sparing no efforts for such (self-made man). A scenario of constant competition, opportunism and utilitarianism rises when people aim to become and continue to be the best, regardless of excessive work routines or abusive labor relations.

What we regard as dangerous, in terms of the analyzed ideology, is its potential for alienating workers and sustaining their domination to a performance culture that does not necessarily lead to the success they pursue as subjects. The primary focus of this ideology is the search for efficiency and activity control, aiming to minimize hazards by using control tools coming from organizations and under the motto of scientific discourse. This causes enormous pressure on the individual, who needs to adapt to the current forms of job exploitation while still being motivated for success. In this sense, anyone who does not conform to the economic standards is doomed to a life of failure and unhappiness.

\subsection{Pop-management: Management tales and literature}

Wood Jr. and Paula (2002) have coined the expression pop-management to refer to the literary manifestation and popularization of management ideology. This phenomenon manifests itself through self-help books, popular business and management magazines, as well as material disseminated in academic circles. It seeks to provide answers to the wishes of individuals and companies with success stories and icons presented as "heroes" (executives, gurus, entrepreneurs), who have managed to solve problems and achieve success. In turn, these icons disseminate formulas and technologies, so others can achieve the same level of success as themselves. 
Pop-management literature emerged in the 1980s when the global context was marked by turbulence and intense competition. That was a favorable period for the emergence of literature focused on a scenario of high instability because its function would be to appease the anxiety of individuals facing professional and personal problems by using resolutions and methods to domesticate subjects (Oltramari, Friderichs, \& Grzybovsk, 2014). During this period, the themes of success, victory, and self-help were intensively explored, disseminated and sold by specialized media through books, magazines, and shows in the mainstream media. The search for quick and easy answers to all workers' problems popularized the business literature in Brazil (Wood Jr. \& Paula, 2002).

Management literature resembles fairy tales, in which the good (represented by the worker or organization) will always prevail over the evil (represented by the continuous problems that appear along the way). As Wood Jr. and Paula (2002) explain, specialized media explore this theme by using the same structure of children's stories or the hero's journey, in which a hero (an entrepreneur, worker or executive) must perform a difficult task. The antagonist is represented as the problem and opposes the hero directly. This antagonist is defeated by the hero through a series of methods (control, vision, innovation, etc.) and the hero is regarded as remarkable because of his achievement - that is, for overcoming the counterforces. At last, the hero is recognized for his good work and perceived as an icon - or an idol.

These tales incite one's imagination, alleviating their tensions and providing hope that the same plot may perhaps happen on their journey as well. The belief in becoming the hero who will defeat evil and triumph, acquiring fame and success, occurs in the subject's own history. In this case, one clings to that tale of success with miraculous formulas and feels delighted. Therefore, pop-management literature comes up with responses and formulas for the individual to use as a kind of springboard to achieve status and become a winner.

According to Ituassu and Tonelli (2014), the physical image of the individual as spread by pop-management media depicts the successful person as a white individual (other ethnicities are treated as "minorities") and usually male (in older versions, the media showed women only as wives supporting their successful husband). As for the age group, most of the publications address young people aged between 24 and 33, who convey the image of innovation and attract a wide range of young readers seeking solutions for their desires. Even the physical appearance is evident: the preference for lean people stands out as compared to overweight individuals, 
who, according to the authors, convey unproductive impressions such as slowness, laziness, and sloppiness. Other unique factors were discussed by the authors, such as beauty, height, and overall dressing style. These characteristics are disseminated as "the features of success" in business media such as Exame and Você S/A magazines, which sell pop-management literature (Ituassu \& Tonelli, 2014).

According to Wood Jr. and Paula (2006), the media organizations that publish such material count on journalists and editors who are not specialized in business and management sciences. These professionals solely aim to publish success stories of individuals and new methods or technologies disseminated by organizations. Besides, these texts stay on the surface of success cases, making it easy for the general public to understand them, although their authors do not have a critical perception of such stories. All the features present in the posts are meant for the public to become interested in successful cases and for the sales to be as high as possible; failure is wholly disregarded, and the complexity of organizations is reduced to a matter of effort.

This whole theoretical apparatus makes us think of pop-management as the sale of success through methods, technologies and success stories, where individuals seek to fulfill their desires and achieve professional and personal goals through quick answers to their dilemmas. Society is buying this "superhuman" image and also mirroring processes previously found only in organizations, with ideals linked to entrepreneurship, managerialism and the cult of excellence, which, as a result, turns the life of individuals into an endeavor to achieve the desired success. What is not evident, in this sense, as it is not expected to be, is that this discourse is, in itself, a power practice that benefits specific social groups - especially those who are directly interested in a self-motivated and anxious workforce population looking for market opportunities.

\section{CRITICAL DISCOURSE ANALYSIS IN ORGANIZATIONAL STUDIES}

When we work with critical discourse analysis, we should seek more than a method, but a theory according to which meaning is sought within social practices (Fairclough, 2003). This happens because the intention of CDA is to interpret and analyze linguistic processes inserted in the social context, so as to show the historically constituted reality. Along these lines, 
two power positions are identified: 1. discourses considered as hegemonic and followed by most of society, which legitimize them as "correct" in a historical process; and 2. resistance discourses, in which individuals do not wish to conform to a given discourse or try to detach themselves from these constraints through other truths.

From Fairclough's (2003) perspective, all texts must be interpreted by considering the historical, social, political, and economic context in which they are inserted. Therefore, every discourse carries an ideological motto and the interest of someone who speaks it. It is enough to reflect, in each idea, about who benefits from an economic and/or political idea, as well as who are the subjects that maintain a certain privileged position for the constitution of an idea. In this sense, still in the view of the aforementioned author, every discourse must be interpreted from the interrelationship of discursive practices and social structures that exist in a dialectical relationship.

For authors such as Magellan (2001), Diniz (2012), and Aguiar and Carrieri (2016), discursive practices are the meaning-giving objects, themes, and symbols that the enunciator passes on to their reader, who, in turn, assigns meanings as intended by the enunciator. Social structures, on the other hand, would be the power mechanisms existing in society, which concern the issue of wealth distribution, the autonomy of the subject, work, ethnicity, social class, gender, etc. Discursive practices and social structures experience a dialectical relationship by determining each other. According to Melo (2011), social structures are legitimized and take shape based on discourses, which are also determined by the social structures that shape individuals and their interests.

Therefore, discourses are historically situated and signified by the established social structures. If an individual identifies with the provided discourse, he or she will propagate it for their particular, as well as social and ideological interests. By obtaining a position of power and a status of domination over other discourses, this discourse will be constituted as hegemonic. On the other hand, where there is hegemony, there is resistance, for these discourses will not always be in the best interest of all people, or will be contraposed by those who are less favored by their ideas (Fairclough, 2003). According to Magalhães (2001), norms, conventions, and ideologies derive from this dynamics or, in other words, the social practices constituted as correct and hegemonic for the society to arise. Truth, in this sense, becomes the discourse determined by the ruling class and by the social relations on a determined societal level in particular institutions (Fairclough \& Melo, 2012). 
So, Fairclough (2003) is interested in discourse - and this object has the text as its primary means of analysis. The text, for the author, is a discursive exercise in which there are several mechanisms, where an opaque reading may allow unobtrusive agreement of the intentional influences of writers (Melo, 2011). For this reason, it is necessary to analyze the semiosis of the expressions, their practices and the power underlying our daily practices in the social environment. To reverse the opacity of the text, Diniz (2012) recommends analyzing some elements, allowing to reveal what is implicit in texts, namely: 1. lexical analysis, or the analysis of the choice of words, expressions, and relations - eventually groups relate to the lexical structure in which a particular shared meaning is internally propagated; 2 . semantic structures, in which reason and meaning are created between the elements of the text, from what is interpreted by the subjects in a given context; and, finally, 3. grammatical structures, which form the texture and the meanings of the words when articulated in sentences.

The structure of the text has more than just grammatical, semantic and lexical linguistic elements; there is a compound of social practices emerging from society and its hegemonies. Therefore, the analysis of texts is necessary for a complete understanding of the messages behind discourse. Fairclough (2003) demonstrates the existence of three primary dimensions for text analysis: action, representation, and identification. The action is the intention of authors to demonstrate their ideology and thoughts behind the linguistic traits, i.e., the authors' action on readers. The representation encompasses the author's conception of the text by exposing their ideals and creating harmony with their readers, who become acquainted with the context presented. The representation also concerns the discourse preached by the author, through which they impose their idealization of thoughts represented in linguistic form and practicing a social activity for their audience (Fairclough, 2003).

Finally, identification concerns the construction of texts, where authors take their stands in relation to the topic that they have elaborated, creating semiosis with readers for the intended interpretation of the roles of author/ reader throughout the text. Therefore, it is possible to perceive the position of the author - someone who speaks with propriety about a certain subject or someone who merely speaks - and of the reader - someone who will consume the author's discourse or someone who should submit to the written word (Fairclough, 2003).

Fairclough developed a six-step CDA analysis to bring about the whole context behind linguistic materials, reversing and critically analyzing the opacity to reveal all the variables behind the text. The first step is to emphasize a social problem with a semiotic aspect: the author usually sees a problem that 
other people do not see; their interpretation diverges from what is set. For who is it a problem? These are questions to be answered.

The second step is the intertextual analysis, consisting of an interpretation that comes from the text in relation to other sources. This can occur in four main ways: 1. attributed intertextuality or what are the citations and references within the text?; 2 . modified intertextuality or what are the expressions of mode? In what way does an idea arise? (e.g., usually, normally etc.); 3. non-modalized intertextuality: what are the categorical affirmations resembling the "truth"? (i.e., that is, this should); and 4. highlighted intertextuality: what are the explicit or hidden assumptions? (e.g., as everyone knows, of course, etc.). From intertextuality, we realize that authors do not speak alone, but in consonance with other texts or other authors that ground it; we also realize that if someone speaks, someone does not, and these aspects are critical to understanding the logic behind intertextuality.

The third step is to discover the obstacles for the problem to be solved, or why a new discourse is not accepted. In this step, we analyze the network practices used in discourse, as well as the particularities of practices and their interaction with the text. The fourth step is to analyze whether the current social order is problematic or not. In other words, are there problems necessary to maintain the existing social order, such as the domination of workers? In asking this question, we must address the hermeneutics of the facts to obtain answers from the analysis of the practices, discourses, and powers generated in the content.

The fifth step is the resolution of the problem, where negative criticism becomes a positive construction in order to change the unconceived reality. It seeks to overcome the obstacles identified, reflecting on how to challenge the status quo and which alternatives are available. This is carried out by showing gaps, failures, and contradictions in the social order imposed by the very practices. The sixth and final step is the critical reflection on the analysis performed, and a self-assessment in relation to all topics analyzed, as well as indications for new CDA studies from the perspective of the text in question. At last, a critical reflection by the analyst on his/her own analysis and the implications of his/her constructions on the object and on the existing power.

In general lines, what is extracted from critical discourse analysis is the fact that it is a method that aims at the critical reconfiguration of a discursive structure and of power in society, by means of opposition; that is, the one who holds power is opposed by the one who does not hold it. Therefore, it is a clash of viewpoints, through which dominations and perversities are revealed behind the exercise of power over weaker subjects within the social structures. In this sense, it is a line of analysis that concerns the emancipation of the powers exercised in society. 


\subsection{The Geração de Valor blog and the "exact science of success"}

The Geração de Valor blog originated from the success story of its founder Flávio Augusto da Silva, creator of the Brazilian language school Wise-Up. In his posts, the businessman repeatedly praises his personal story as an entrepreneur who emerged from poverty with the dream of succeeding, his only capital in the 1990s being a 20,000 BRL check to leverage his company. Over the years Flávio da Silva achieved success in his business, and in 2013 he sold his franchise network for 877 million BRL (444 million USD). Later, he became the largest shareholder of the media group Abril, and this transaction brought him notoriety - his public figure became synonymous with the semblance of a hero who overcame poverty to become one of the wealthiest and most influential men in the country.

His Facebook page has over 3 million followers, and the page description states that "success is an exact science that all can learn." With this motto, the author gives hope to countless Brazilians who dream of success. Moreover, Geração de Valor is also present in the pop-culture literature market. A 2016 best-seller in the business category, his book Geração de Valor 2 ranked second with 35,410 copies sold, whereas the first edition called Geração de Valor ranked fifth with 28,635 copies sold ${ }^{1}$. To carry out the analysis, a sample consisting of six texts from the blog has been assembled:

\section{(Chart 3.1.1)}

TEXTS FROM GERAČÃO DE VALOR TO BE ANALYZED

Text from the Blog analyzed:

For those of you who are part of the $0.001 \%$

Who is the biggest employer in Brazil?

The wall still stands

Work for real

For the champions

Two superpowers needed to win

Source: Elaborated by the authors.

Retrieved from http://www.publishnews.com.br/ranking/anual/8/2016/0/0 
The texts were chosen according to an intentional cut and to our convenience because we sought texts that illustrated the ideas disseminated on Flávio da Silva's internet blog. After the selection, a systematic reading of the texts was carried out, contrasting them with the questions asked in each of the six steps of Fairclough's Discourse Analysis. The lexical choices, the intertextualities contained in the documents, as well as the practicaltheoretical issues raised from the frame of reference selected (management ideology and pop-management), were analyzed. After performing CDA procedures, the analysis was written in a narrative format in which all aspects regarded as relevant in the enunciator's discourse were pointed out, and the opacity of the texts was reversed by means of discursive strategies and strategic positions regarding management ideology.

We understand that the care reading these texts is necessary for the current context. The referred book by the blogger of Geração de Valor currently occupies, along with other books of the same nature, the shelves of renowned bookstores, which sell such content as theoretical knowledge in the field of administration. In this sense, to critically analyze such texts it is necessary to denounce management ideology and strategies as part of the capitalist control project in the world (Rampazo, 2015).

\section{WHAT ARE THE DISCOURSES EMBEDDED IN GERAÇÃO DE VALOR?}

Every time we have followed the dynamics of business education in the media and in academia, we have recurrently come across the discursive practice of believing that everything and everyone around us is fully controllable through methods and techniques. However, we cannot fail to recognize that human beings are social beings, historically situated, constituted by a multitude of cultures and ideologies that sometimes converge, sometimes conflict. The question left hanging in the air is: can one control human subjectivity? Can one control all the historical, social, economic and political variables in which human beings are inserted? For the blogger, it seems so. Catchphrases in this direction include:

Building a winning mentality means being determined to develop your projects in any scenario. And to not depend on the goodwill of politicians, or be held hostage to external factors. [...]. Learn to take control. Stop setting your hopes on politicians. Learn to live as those who are the masters of their time and destiny (Silva, 2016b). ${ }^{2}$

2 All translations and empahsis in Silva (2015a; 2015b; 2016a; 2016b; 2016d) were added by the authors. 
Through this speech, the writer claims that we are all able to achieve the desired success regardless of what happens in the meantime. According to this view, factors such as remuneration, access to credit, employment policies, political models and cultures in society do not affect the volitional condition of the subject in any instance. In other words, the innocently proposed perspective believes that the only factor necessary for success is willingness, even in famine scenarios marked by poverty and social exclusion. The author acknowledges that his vision will not be "understood" by all since he stands as a true optimistic regarding life choices. The outcome of his personal history and experience has taught himself how to cope with the criticism from those who consider him distant from the different realities experienced in Brazil. In this sense, he replies:

The truth is that life is short. If you want to be a champion, you need to think like a champion. If that's what you want, be prepared to be called selfish, arrogant and to be told that you lack a social conscience. This is because the will to succeed in life eventually becomes something immoral, as a result of this brainwashing with sewage water. After all, being a loser has become fashionable in recent years, without our youth noticing it (Silva, 2015b).

What is apparent in the author's discourse is not exactly a matter of optimism or faith, but a mere lack of empathy to the conditions of those who are not motivated to seek a pre-determined success model marked by inequalities and selectiveness over opportunities. It may even reveal indifference as for the uniqueness of everyone's life histories and overcoming stories of different subjects throughout their lives. The use of the term "brainwashing with sewage water" [sic] indicates how much he despises human empathy and reciprocity conditions and evince his indifference towards those who think differently regarding a collectivist project of society.

The rejection of the idea of a society politically established through dialogue, agreement and social consensus regarding the means of production, as well as the distribution of power and a sense of redistribution of wealth is very evident in the author's writing. This is because he understands that the masses are not trained to have an individualistic lifestyle, meritocratic, and turned to significant achievements. In fact, according to the author, the masses "are trained to depend on the system, remain subdued and feel victims, rather than being/becoming "masters of their own destiny" (Silva, 2016b). In this sense, 
For you to surrender to collectivism, they will blackmail you, call you selfish, they will tell you that you just gaze into your own navel, that you are an accomplice of the world's injustices and so on, until your individual dreams are mercilessly suffocated and replaced by a position in the crowd, perhaps holding a banner or screaming in the middle of the masses, led by someone above any suspicion in favor of the community and of a supposedly noble cause for which, in their view, anything is worth, even sacrificing your own life (Silva, 2016a).

The implicit (or ironically explicit) reference in that discursive stretch is that any social or collective well-being ideals connected to an ideology which prioritizes the collective as superior to the individual is dull and inferior to the status obtained by those who "dare" to seek to achieve success on their own. However, we invite readers to a brief reflection about the author's contradictions. The first is that he criticizes the masses using popular media to address to... the masses themselves! That is, he teaches the members of the masses not to associate with one another, but to remain in a solitary position. Split to win. Who is interested in individualism in the masses? Another important point is the lexical selection of the expression "individual dreams are mercilessly suffocated," which alludes to the idea that something such as an individualistic dream is a valuable and a target for the destructive intentions of the "murderous villains of dreams".

As an entrepreneur, it is convenient for the author to show those who dream of being in a similar position what the proper behavior to be followed should be, so that they can achieve an economic and social level as attractive as his. The author poses himself as an object of desire for his readers. He seduces each of them through his achievements. He wants them to follow their dreams above everything and everyone. He states that nothing can stop them from achieving success. A self-motivation profile, boundless and utterly lonely is the perfect ideal of an ambitious worker who can stand and face whatever challenges may lie ahead, even if these are dehumanizing.

Work, in this sense, is treated as a means for the individual to conquer their individual dreams, regardless of what conditions they are subjected to. Regardless of whether the working day is incredibly exhausting. Regardless the stress level. In this view, working is not a penance, but a gift. Therefore, these are the blogger's words about work, to those who do not submit to the Homeric ideal of effort aimed at the result:

Working does not make you tired. What makes you tired is not getting anywhere, not seeing prospects and not feeling accomplished with 
your yields. Working is not a penance. A penance is to lag because of the wrong choices, to not fulfill your dreams for lack of courage and to be one in a million, guided by common sense. Working is not a place to attend. To work is to produce, is to move from point $A$ to point $B$. To work is to make a difference (Silva, 2016d).

In other words, to work is the solution to men's problems. It is precisely the way to go for achieving the desired great victory. And it only depends on the efforts and productivity of each subject. Yet, useless work does not suffice; we need to produce and to do so in an efficient and effective manner. Through this disco urse, the masses to which the texts are targeted are gradually guided to the unwavering belief in work as human salvation and transcendence.

However, we argue: is working in our contemporary capitalist model indeed the formula for success? If we are talking about material success that leads to a more favorable social and political status or even the inclusion in the economic elite, we are also talking about dedication to a relationship of exploitation of the workforce and dedication to the capitalist market that, eventually, will take its toll of time and effort in exchange for non-equivalent rewards. This discourse is rather convenient for those that eventually benefit from faithful work - whether by setting up a new company or in everyday life of organizations. However, a question that further strikes the eye is: what is this so-called "success"? According to Silva, success is an "exact science," i.e., something to be taught to all. Success is

To fulfill your life mission. For someone whose purpose is to engage in a humanitarian mission, success can be measured by the number of lives saved. For an entrepreneur, success can be measured by the value he generates in his company. Everyone has their own mission. The success of each one varies according to the chosen mission. And in many cases, success may be followed by financial recognition. However, not fulfilling your mission in life means to deep dive into the murky and smelly waters of stagnation (Silva, 2015b).

Despite all the challenges to succeed in life and fulfill their mission, one of the biggest threats that leads young people to waste their potential are the mediocre ideologies often preached at the schools, universities, clubs, churches or by the political parties. Ideologies that form defeated thinkers to preach a doctrine that nullifies their leadership and initiative and, on the other hand, encourages victimhood and a perception that the State must support them (Silva, 2015b). 
For the author, success is movement or the engagement to a purpose. A purpose that, in some cases, leads to "financial recognition" [sic]. In this sense, recognition is a term that hides that remuneration is the retribution of labor provided according to its market value - obeying the supply and demand criterion. To be recognized is to succeed. Failure, on the other hand, lies in stagnation, or non-execution of the tasks expected for those who aspire a certain goal. This is the typical formula of management ideology: setting goals and targets and, through actions, achieving these goals. An interesting point in the author's discourse is that the mentality of success may suffer "deviations" over human education. These may occur at school, college or in spaces where the subject may be exposed to ideas that nullify or counteract the notions of leadership and heroism to the detriment of their "obvious" antagonists, which, according to the author's words, are the "victimhood" and stagnation of men.

From the author's perspective, the secret of success lies in his own life. That is, in his achievements, consumption patterns, way of dealing with problems, interpretation of labor, and especially the notion of triumph and social approval of his deeds. In a remarkable attitude of narcissism, he stands as an ideal model or a hero to be followed by those who wish to raise great empires in their lives. In several passages, the author praises his personal stories and the benefits of being who he is. He directs his discourse to seduce society to his lifestyle and to the fact that he has been able to overcome all challenges and difficulties through his own efforts.

Despite being unbelievable nonsense, when I tell people outside of Brazil about this phase of my life, and I am often asked to tell details of my first steps, they fail to believe it. However, for the peripheric mass, it is part of their routine to face suffering with naturality, some even with good humor. After all, to make the crossing is necessary to overcome this stage until you can move closer. Where does this strength come from? It comes from a special superpower that such human beings develop, a kind of supernatural resilience that keeps them alive in the game of life. There is no choice. It is do or die. That is a superpower quite rare among superheroes: nerves of steel (Silva, 2015a).

[...] entrepreneurs who become successful are very well rewarded. They feel pleased to have built their project, gain independence from this disgusting system and are very well paid. [...] If only $1 \%$ more Brazilians began to seek the rewards generated by the successful and honest enterprise, 
millions of new jobs would be created, the economy would take off, and the State would raise more taxes. Everyone wins (Silva, 2016c).

It is from the analysis of the highlighted passages that we find the essence of management ideology, as well as demonstrations in the form of pop-management. We finally have a hero with superpowers. The cycle closes. There is a narrative. We know what we want. In short, the individual only needs goals and objectives in their environment to reach the status of desired success. They must isolate themselves from the masses. They should work nonstop, regardless of the barriers. They should be great heroes and selfmotivated to work. They must get away from the "failure from stagnation" and "rotten victimhood." The readers of Geração de Valor have a scientific formula to achieve the desired success and to flourish their individual dreams. It is enough to follow their "shepherd" and the way of life preached by him. He is able to teach and guide the methods and means applicable in this new science - which brings the full promise of thriving.

\subsection{Discourse analysis: Reversing opacities}

We realize that the grand reference to the author's discourse is the neoliberal and meritocratic bias that has been widespread by the media in recent years. Now, it is precisely this kind of discourse that has legitimized the economic practices that sustain the current capitalist basis. The successful entrepreneur is always justified by the workers' production gain - customarily treated as alienated masses who tend to conformism and victimhood and who beg for State intervention to reduce inequalities. To praise and defend these neoliberal positions does no more than defend and sustain the author's privilege positions, especially in his discursive condition that poses success, accumulation of wealth and social prestige as largely positive and virtuous deeds to be pursued by all other human beings. This is the reproduction of the logic of a power that has already been established and has seduced the working classes for many years.

We also realize that Flávio Augusto's voice is nothing more than one of the many voices seeking to defend, including in the field of administration, the cult of personal victory and disdain for the collectivist practices of social organization. Throughout his writing, any divergence to his views is referred to as "smelly" and "mediocre," indicating the clear position of the enunciator towards the object of his discourse. Thus, any form of manifestation from the collective, associated work are futile and do not lead, at any level, to 
one's personal satisfaction. From this perspective, the real satisfaction comes from the individual rewards. The author also assumes that the reader will be seduced by his successful figure - after all, for him, it seems inconceivable that someone does not wish the milestone of success and victory in his or her own personal history. Any construction concerning a sum of efforts and reciprocal relationships are muted throughout the text.

What does the author want, anyway? Nothing more than dismantling the working masses, so that everyone pursues his ideal of victory through continuous work and uncritical devotion. It is a practice of faith based on principles disseminated by management ideology. Furthermore, he seeks to standardize the conduct of readers through provocation and language strategies so that they come to see themselves in the condition of merely following the advice from someone who has experienced all forms of success and is able to guide the subject's conduct.

It is challenging to counteract such discourse when the media and the academia insistently aim to create a culture so directed to the legitimacy of a neoliberal and meritocratic ideal. The disarticulation of workers is interesting because once dismantled, they shall not question their respective positions of power or the domination practices to which they are subjected on a daily basis. Any resistance to these constructions require critical thinking by readers and this can only be built through a more humanistic and social education - especially with regard to educational spaces, which are not intended to be only technical training for "ravenous lions of the market", but also the formation of autonomous subjects, able to critically think and interpret the environment around themselves. Unfortunately, this is not the present reality of most Brazilian citizens, who are in fact still seduced by the discourse of consumerism and material gain as a fundamental source of personal joy.

The means used are targeted precisely at population groups that do not have resources to acquire access to the best schools and business education media. Flávio Augusto seeks to teach success without necessarily teaching how to manage. His approach merely entices those who do not have more profound knowledge of administrative practices and also aims to present the entrepreneur's life as a fictional tale that allows us to dream of being "happily ever after," in a somewhat sensationalist way. In an environment in which lower-class population groups are hostages of few opportunities and struggle to make a living, the blog discourse is a perfect siren song to recruit new followers. 
Why is this a problem? Because it incites the false perception that success only depends on one's work; that every human being is devoid of a context and a history; that work can be carried out at dehumanizing levels towards an ideal of success that is unattainable for those whose conditions are precarious. Added to that, because it generates a large disarticulation between those who are not favored by the neoliberal economic practices, and finally because it keeps the oppressed in a dormant state of domestication for the continued exploitation of their workforce and human strength for the production of goods. This type of discourse can only be sustained as long as there is inequality; at the moment when workers realize the value of their association or their union, the idea that every entrepreneur will be "rewarded financially" for their success will collapse, as this value, in fact, can and should be directed to the one who created it - the employee.

Even faced with the difficulty to counter the massive media business, we believe that resistance can happen through the critical exercise of market practices and the administration literature - especially with regard to education. That is because these statements and certainties may be gradually opposed by renowned professionals who present alternative perspectives and discourses that may guide us all towards the good of society, rather than the individual good. The individualistic position, as presented throughout this paper, does no more than legitimizing the concentration of resources in the hands of a few heroes, while most of the population can only dream of it.

If we consider that the author is right in his remarks, we are doomed to become envious and frustrated beings, especially if we fail in our own game of "life as an enterprise". We shall then forget the values of failure, and only give importance to success. We shall forget the human and social values of work, and focus only on the production and financial results achieved over the dehumanizing routines to which we are subjected. Finally, we shall abandon any and all opportunities to reorganize ourselves as a society that aspires the end of the inherent social inequalities and put into practice a collective project that allows everyone an equal opportunity and a better life.

\section{FINAL CONSIDARATIONS: WHAT IS LEFT OF THAT DISCOURSE, THEN?}

To conclude all the remarks analyzed so far, it is important to position ourselves in relation to the content we produced through our own discourse. This is because our purpose as authors is not to categorically state that the 
values of effort and dedication are useless in society. Much less is our intention to say that success of the individual is something unattainable. Our criticism in this paper is targeted at the fact that success has been marketed as a product in a harmful and superficial way.

Throughout this paper, we have focused our efforts on exposing and deconstructing discourses that, in our view, do no more than inciting workers to pursue a lifestyle that has been notoriously detrimental to health and happiness. In a moment when we are witnessing a neoliberal breakthrough and the reduction of worker's rights in Brazil, it is increasingly important that we take positions as for the various discursive forms that are restoring retrograde labor practices of the past. One can think of a new administration - one that focuses on the jobs the realization of man, but not grounded on the sole issue of "financial reward" or the desired level of consumption. In other words, labor and management are much more than what the gurus and the business media make it look like.

We believe that the contribution of this study is applied. The purpose of our work is to contribute to the field by revealing the discursive strategies used to maintain positions of power in management studies, specifically in the case of the Geração de Valor blog, which has become popular in promoting entrepreneurship and management contexts. Added to that, we wish to warn our readers for the possibility of graduate students and professionals to abandon the reading and study of scientific and philosophical theories of management in favor of generic and superficial knowledge that has been strategically developed to weaken the critical skills of workers.

Moreover, the purpose of the article is to demonstrate the potential of critical discourse analysis as a form of denouncing the knowledge and the discourses naturalized in everyday life of organizations. Our ambition as authors is to demonstrate a systematic way to articulate these arguments and how one can counter them to a critical vision that brings to the fore the statements, strategies and hidden meanings desired by enunciators - so that the non-existence of alleged neutrality in management becomes apparent.

In our view as authors, to criticize these practices is not to delegitimize the science of administration. Instead, it is to assume the political position to defend it as a possibility of social transformation. To achieve this, critical education and the search for new ways of thinking are paramount for the construction of the future. Hence, this is an invitation not only for readers to take positions regarding what they read in this paper, but also to critically reflect about the discursive movements witnessed in the field of administration. 


\section{GERAÇÃO SEM VALOR? O SUCESSO É UMA CIÊNCIA EXATA QUE TODOS PODEM APRENDER!}

) RESUMO

Objetivo: O objetivo geral é analisar criticamente, por trás dos discursos criados em torno do sucesso, as ideologias e construções do management no Blog "Geração de Valor".

Originalidade/relevância: O fenômeno Pop Management tem sido popular no contexto brasileiro. Nele, os indivíduos buscam fórmulas para se sobressair e ganhar seu lugar de sucesso como empreendedores. Um dos disseminadores dessa ideologia tem sido o blog "Geração de Valor". Este artigo inova ao tratar da temática sem estrelismos e fantasiosos romantismos.

Principais aspectos metodológicos: Este artigo busca, por meio da Análise Crítica do Discurso (ACD), analisar alguns textos do Blog Geração de Valor.

Síntese dos principais resultados: Percebemos que a voz de Flávio Augusto nada mais é do que uma das várias vozes que buscam defender, inclusive no campo da Administração, o culto à vitória pessoal e o desdém às práticas coletivistas de organização social. Análises desta natureza ainda são escassas no campo, pois demandam leituras enriquecidas do texto em relação ao contexto e à intertextualidade. Análises críticas contrapõem visões hegemônicas e aguçam o senso crítico do leitor. Além disso, são úteis em evidenciar o culto midiático que a Administração vem recebendo.

\section{PALAVRAS-CHAVE}

Management. Ideologia. Poder. Análise Crítica do Discurso. Teoria Crítica.

\section{REFERENCES}

Aguiar, A. R., \& Carrieri, A. D. (2016). "Água de lona" e "sangue de serragem" nos discursos de sujeitos circenses. Organizações \& Sociedade, 23(77), 247-262. doi:10.1590/1984-9230774 
Barros, A. N. (2014). Uma narrativa sobre os cursos superiores em Administração da FACE/UFMG: Dos primeiros anos à sua unificação em 1968. Cadernos EBAPE.BR, 12(1), 7-25. Retrieved from http://biblioteca digital. fgv.br/ojs/index.php/cadernosebape/article/view/9178/17307

Brasil. (2017). Desemprego volta a cair em agosto, diz IBGE. Brasília, DF, Brazil. Retrieved from http://www.brasil.gov.br/economia-e-emprego/2017/09/ desemprego-volta-a-cair-em-agosto-diz-ibge

Carvalho, J. L., Carvalho, F. A., \& Bezerra, C. (2010). O monge, o executivo e o estudante ludibriado: Uma análise empírica sobre leitura eficaz entre alunos de administração. Cadernos EBAPE.BR, 8(3), 535-549. Retrieved from http://bibliotecadigital.fgv.br/ojs/index.php/cadernosebape/article/ view/5171/3905

Diniz, A. P. (2012). Mulheres gerenciáveis? Uma análise dos discursos sobre as mulheres na revista Exame (Master's thesis). Belo Horizonte, MG, Brazil. Retrieved from http://www.bibliotecadigital.ufmg.br/dspace/handle/ 1843/BUBD-92XHRW

Fairclough, N. (2003). Analysing discourse: Textual analysis for social research. Londres, UK: Routledge.

Ituassu, C. T., \& Tonelli, M. J. (2014). Sucesso, mídia de negócios e a cultura do management no Brasil. Cadernos EBAPE.BR, 12(1), 86-111. Retrieved from http://bibliotecadigital.fgv.br/ojs/index.php/cadernosebape/article/ view/9313/17311

Magalhães, C. M. (2001). A análise crítica do discurso enquanto teoria e método de estudo. In C. M. Magalhães (Org.), Reflexões sobre a Análise Crítica do Discurso (pp. 15-30). Belo Horizonte, MG: Faculdade de Letras da UFMG.

Melo, I. F. (2011). Análise crítica do discurso: Modelo de análise linguística e intervenção social. Revista Estudos Linguísticos, 40(3), 1335-1346. Retrieved from https://revistas.gel.org.br/estudos-linguisticos/article/view/1257/ 807

Oltramari, A. P., Friderichs, B. D., \& Grzybovsk, D. (2014). Carreira, família e a dialógica do assujeitamento: $\mathrm{O}$ discurso vigente em uma revista popular de negócios. Cadernos EBAPE.BR, 12(1), 112-130. Retrieved from http:// bibliotecadigital.fgv.br/ojs/index.php/cadernosebape/article/view/9630/ 17312

Paula, A. P. (2016). Em busca de uma ressignificação para o imaginário gerencial: Os desafios da criação e da dialogicidade. Revista de Administração da Mackenzie, 17(2), 18-41. doi:10.1590/1678-69712016/administracao.v17 n2p18-41 
Rampazo, A. V. (2015). O management e o projeto de controle do mundo. Revista de Estudos Organizacionais e Sociedade, 2(4), 569-619. doi:10.25113/ farol.v2i4.2760

Santos, M. D., Fonseca, A. C., \& Sauerbronn, F. F. (2014). Cultura organizacional e avanço do management na Marinha do Brasil. Cadernos EBAPE.BR, 12(1), 131-162. Retrieved from http://bibliotecadigital.fgv.br/ojs/index. $\mathrm{php} /$ cadernosebape/article/view/9417/17650

Silva, F. A. (2015a). Dois super-poderes necessários para vencer. Retrieved from http://geracaodevalor.com/blog/dois-super-poderes-necessarios-paravencer/

Silva, F. A. (2015b). Para os campeões. Retrieved from http://geracaodevalor. com/blog/para-os-campeoes/

Silva, F. A. (2016a). O muro ainda está de pé. Retrieved from http:// geracaodevalor.com/blog/o-muro-ainda-esta-de-pe/

Silva, F. A. (2016b). Para você que é parte do 0,001\%. Retrieved from http:// geracaodevalor.com/blog/para-voce-que-e-parte-do-0001/

Silva, F. A. (2016c). Quem é o maior empregador do Brasil? Retrieved from http://geracaodevalor.com/blog/quem-e-o-maior-empregador-do-brasil/

Silva, F. A. (2016d). Trabalhe de verdade. Retrieved from http://geracaodevalor. $\mathrm{com} / \mathrm{blog} /$ trabalhe-de-verdade/

Uusitalo, R. (2001). Homo entreprenaurus? Applied Economics, 33(13), 16311638. doi:10.1080/00036840010015778

Wood Jr., T., \& Paula, A. P. (2002). Pop-management: Contos de paixão, lucro e poder. Organizações \& Sociedade, 9(24), 39-51. doi:10.1590/S1984-9230 2002000200003

Wood Jr., T., \& Paula, A. P. (2006). A mídia especializada e a cultura do management. Organizações \& Sociedade, 13(8), 91-105. doi:10.1590/S198492302006000300006

Žižek, S. (1996). O espectro da ideologia. In S., Žižek (Org.), Um mapa da ideologia (pp. 7-38). Rio de Janeiro, RJ: Contraponto.

\section{AUTHOR NOTE}

Rodolfo G. S. P. G. Prates, Centro de Ciências Sociais Aplicadas (CCSA), Universidade Estadual de Montes Claros (Unimontes), ORCID:0000-0002-2200-2432; Isabela L. Santos, Centro de Ciências Sociais Aplicadas (CCSA), Universidade Estadual de Montes Claros (Unimontes), 
ORCID:0000-0001-5434-7235; Jardel N. Martins, Centro de Ciências Sociais Aplicadas (CCSA), Universidade Estadual de Montes Claros (Unimontes), ORCID:0000-0003-1105-7953; Fabiana S. A. Martins, Centro de Ciências Sociais Aplicadas (CCSA), Universidade Estadual de Montes Claros (Unimontes), ORCID:0000-0002-6263-5234; and Felipe F. Couto, Faculdade de Ciências Econômicas (FACE), Universidade Federal de Minas Gerais (UFMG), ORCID:0000-00024928-9920.

Felipe F. Couto is now at the Centro de Ciências Sociais Aplicadas (CCSA), Universidade Estadual de Montes Claros (Unimontes), Montes Claros, MG, Brazil.

Correspondence concerning this article should be addressed to Felipe F. Couto, Centro de Ciências Sociais Aplicadas (CCSA), Universidade Estadual de Montes Claros (Unimontes), Campus Universitário Professor Darcy Ribeiro, Prédio 1, Sala 304, Vila Mauriceia, Montes Claros, MG, Brazil, CEP 39401-089.

E-mail: felipe.couto@unimontes.br

\section{EDITORIAL BOARD}

Editor-in-chief

Silvio Popadiuk

Associated Editor

Silvia M. R. Domenico

Technical Support

Vitória B. S. Silva

\section{EDITORIAL PRODUCTION}

Publishing Coordination

Irina Migliari

Language Editor

Daniel Leão

Editorial Trainee

Maria Luiza Vanz

Layout Designer

Emap

Copyeditor

Irina Migliari

Graphic Designer

Libro 